\title{
ANALISIS MARKET SEGMENTATION, TARGETING, DAN POSITIONING TRANSPORTASI ONLINE GRAB DI KOTA BOGOR (STUDI KASUS PADA MAHASISWA UNIVERSITAS PAKUAN)
}

\author{
Herdiyana dan Salmah \\ Fakultas Ekonomi Universitas Pakuan \\ Email: herdiyana@unpak.ac.id dan salmah azz@yahoo.com
}

\author{
ARTICLE INFO \\ Article History: \\ Received 10 Dec 2018 \\ Revised 20 Dec 2018 \\ Accepted 10 January 2019 \\ JEL Classification: \\ D40, D47 \\ Keywords: \\ Segmenting, \\ Targeting, and \\ Positioning Online \\ Transportation Grab
}

\begin{abstract}
This research aim is to find out the segmenting, targeting, and positioning on online transportation Grab in Bogor City by using Pakuan University students as the research sample. This research uses descriptive survey method to researches the phenomenon about online transportation service and learns various relevant aspects with segmenting, targeting and positioning. The population of the researhes is 14.138 student of Pakuan University and 389 students were taken as the sample. The sampling method uses probability sampling with proportional cluster sampling technique, the determination of the number of samples using the Slovin method. The results of this research shows the segmentation from online transportation Grab in Bogor City which is from West Bogor, used by most female, having home lifestyle, and having extrovert personality. The reason using Grab is for travelling and looking for convenience and paying the cheap price compared with the competitors. Grab users know that Grab having promos through Grab application. Loyalty Grab users are included in enough loyal category. Target market from Grab is selective specialization, on this market pattern, Grab enters a number of market segmentation by offering different products. And for this thing Grab enters segmentation as a transportation tool and also as goods delivery service. Grab positioning is to make their brand staying in consumer's mind from usage side, which is as a transportation tool and service that provides convenience, comfort, safe, and fast.
\end{abstract}

\section{PENDAHULUAN}

Tahun 2015 merupakan masa yang fenomenal bagi perkembangan layanan transportasi on demand, atau yang biasa dikenal dengan transportasi online (transonlinewatch.com, 2018). Lahirnya transportasi online dipicu oleh kondisi lalu lintas di ibukota Jakarta yang semakin hari semakin macet dikarenakan bertambahnya volume kendaraan dan banyaknya pembangunan yang mengambil space jalan untuk kendaraan. Masyarakat ibukota pun dituntut untuk berangkat lebih pagi agar dapat terhindar dari kemacetan. Sebagai alternatif 
banyak masyarakat ibukota yang akhirnya beralih menggunakan transportasi roda dua untuk menghindari kemacetan dan mengejar waktu, baik itu dengan menggunakan sepeda motor milik pribadi atau dengan menggunakan jasa ojek. Hal inilah yang memicu seorang Nadiem Makarim yang berdasarkan pengalamannya sebagai pengguna gojek, terpikir untuk memudahkan penumpang dan pengojek terhubung dengan aplikasi smartphone. Hingga pada tahun 2015 lahirlah aplikasi Gojek.

Gojek sendiri sebenarnya sudah dirintis pada tahun 2011, tapi pada tahun 2015 sejak peluncuran aplikasinya di ponsel Android dan iOS membuat layanan ini melesat (Detik.com, 2017). Dalam rentang waktu dua belas bulan, GOJEK berkembang dari sebuah aplikasi mobile baru menjadi sebuah layanan besar, yang kemudian mendapat perlawanan dari GrabTaxi dengan layanan GrabBike. Persaingan tersebut pun semakin sengit dengan masuknya layanan transportasi online asal Amerika Serikat yaitu Uber, yang hadir ditanah air sejak tahun 2014 (Techinesia, 2017).

Munculnya Grab dan Uber menambah warna persaingan dalam transportasi online. Berdasarkan survey yang dilakukan oleh YLKI (Yayasan Lembaga Konsumen Indonesia), aplikasi Gojek menduduki rating tertinggi yang dipilih konsumen yaitu sebanyak $72,6 \%$, kemudian Grab sebanyak 66,9\%, Uber sebanyak $51 \%$ dan terakhir My Bluebird sebanyak 4,4\%. Alasan para konsumen menggunakan transportasi online pun beragam diantaranyaadalah murah sebanyak $84,1 \%$ konsumen, cepat sebanyak $81,9 \%$, nyaman sebanyak $(78,8 \%)$ dan aman sebanyak 61,4\% (Tribunnews, 2018).

Studi dari ilmuOne Data dengan sumber data yang diperoleh dari comscore mengungkap jumlah pengguna Grab dan Gojek tidak jauh berbeda yaitu 8,6 juta perbulan dan 8,8 juta per bulan, sementara untuk Uber sekitar seperempatnya yaitu 2,3 juta per bulan. Uniknya 4 juta dari pengguna
Gojek juga merupakan pengguna Grab, sedangkan 15,8\% dan 16,9\% pengguna Gojek dan Grab masing-masing menggunakan Uber. Namun, 60\% pengguna Uber menggunakan Gojek dan Grab (liputan6.com, 2017).

Ketatnya persaingan dalam dunia transportasi online, membuat perusahaan transportasi online Grab mengambil strategi untuk mengakuisisi Uber per 26 Maret 2018 seperti dilansir oleh Kompas.com. Bergabungnya Grab dan Uber akan semakin memperluas jaringan layanan transportasi online Grab, dengan akuisisi ini driver uber secara otomatis menjadi driver Grab, dan data pengguna Uber menjadi pengguna Grab, dan aplikasi yang digunakan tidak lagi menggunakan dua aplikasi tetapi menjadi satu aplikasi yaitu aplikasi Grab. Untuk dapat terus eksis dalam bisnis transportasi online, Grab dituntut untuk memiliki keunggulan yang membedakannya dengan pesaing dan setiap brand harus memiliki ciri khas yang diingat oleh para konsumennya.

Pada kondisi pasar heterogen, perbedaan perilaku pasar harus ditanggapi secara benar bila ingin berhasil dalam kegiatan pemasarannya. Konsumen dalam berbagai aspek mempunyai perilaku yang berbeda dan seringkali tidak dapat dikelompokkan dalam suatu kelompok besar yang mempunyai perilaku serupa secara umum. Oleh karena itu, perusahaan perlu melakukan pengelompokkan konsumen menjadi berbagai segmen pasar tertentu (Adisaputro,2014,99). Menentukan pilihan segmen pasar yang akan dilayani dan bagaimana strategi pemasaran yang akan diterapkan di tiap-tiap segmen pasar tersebut merupakan salah satu keputusan manajemen yang paling penting bagi setiap jenis perusahaan (Sutojo, 2009).

Tjiptono dan Chandra (2012) berpendapat bahwa "segmentasi pasar diartikan sebagai proses mengelompokkan pasar keseluruhan yang heterogen menjadi kelompok-kelompok atau segmen-segmen yang memiliki kesamaan dalam hal kebutuhan, keinginan, perilaku dan/atau respon terhadap 
program pemasaran spesifik". Segmentasi pasar dilakukan dengan mengelompokkan pasar konsumen dengan menggunakan beberapa jenis variabel, Oentoro $(2010,43)$ menyatakan ada 4 variabel yang digunakan yaitu: geografis, demografi, psikografik, dan tingkah laku.

Setelah segmentasi atas produk ditetapkan, maka langkah berikutnya adalah melakukan targeting atau membidik target market yang telah dipilih dalam analisa segmentasi pasar. Gunawan Adisaputro (2014) terdapat beberapa pilihan strategi yaitu strategi konsentrasi segmen tunggal, strategi spesialisasi selektif, strategi spesialisasi produk, strategi spesialisasi pasar, dan strategi cakupan pasar keseluruhan.

Dengan ditetapkannya strategi yang akan diambil oleh perusahaan, langkah berikutnya adalah melakukan positioning produk. Langkah ini artinya adalah menciptakan keunikan posisi produk dalam benak atau persepsi pelanggan potensial yang akan dibidik (Wijaya dan Sirine, 2016). Peter dan Olson (2014) sedikitnya ada 5 (lima) pendekatan untuk strategi pemosisian antara lain berdasarkan: atribut, penggunaan atau aplikasi, pengguna produk, kelas produk, dan pesaing.

Penyusunan STP yang tepat dibutuhkan oleh perusahaan transportasi online Grab. Kondisi persaingan yang ketat dialami perusahaan transportasi online Grab yang berada pada pasar yang heterogen, dimana dari sisi geografis memiliki segmen yang sama dengan pesaing yaitu berada di seluruh kotakota besar di Indonesia. Sebagai contoh untuk kota Bogor yang bukan merupakan kota besar di Indonesia, masyarakat dapat menikmati jasa transportasi online Gojek dan Grab dengan mudah.

Penelitian yang mendukung pernyataan di atas telah dilakukan oleh Sylvia, dkk. (2016) dimana banyaknya kompetitor pada produk pia mangkok membutuhkan strategi pemasaran yang mampu mempertahankan daya saing. Oleh karena itu, dibutuhkan rancangan STP sebelum merancang strategi pemasaran. Berdasarkan rancangan tersebut diperoleh bahwa produk pia mangkok memiliki keunggulan dari segi rasa, packaging, dan harga terjangkau.

Dengan mempertimbangkan latar belakang diatas, maka penting bagi perusahaan transportasi online Grab untuk menentukan strategi pemasaran seperti market segmentation, targeting, dan positioning. Dengan menerapkan strategi tersebut diharapkan perusahaan dapat bersaing dalam dunia transportasi online yang semakin ketat. Penulis tertarik untuk melakukan analisis segmenting, targeting, dan positioning pada salah satu transportasi online yang baru saja melebur dengan pesaingnya yaitu Grab, dengan mengambil sampel penelitian pengguna Grab di Kota Bogor, yaitu mahasiswa Universitas Pakuan. Oleh karena itu penulis, tertarik membuat penelitian yang berjudul: Analisis Market Segmentation, Targeting dan Positioning Transportasi Online Grab di Kota Bogor (Studi Kasus pada Mahasiswa Universitas Pakuan).

Adapun tujuan dari penelitian ini adalah untuk mengetahui segmenting, targeting, dan positioning transportasi online Grab di Kota Bogor dengan mahasiswa Universitas Pakuan sebagai sampel.

\section{TINJAUAN PUSTAKA}

\section{Market Segmentation}

Menurut Mullins dan Walker $(2013,180)$ berpendapat bahwa "Market segmentation is the process by which a market is divided into distinct subsets of customers with similiar needs and characteristics that lead them to respond in similiar ways to a particular product offering and marketing program".

Sedangkan segementasi pasar menurut Kasali dalam Oentoro (2010) mendefinisikan segmentasi pasar sebagai berikut:

Segmentasi pasar adalah kegiatan
membagi


kelompok-kelompok pembeli yang berbeda yang memiliki kebutuhan, karakteristik, atau perilaku yang berbeda yang mungkin membutuhkan produk atau bauran pemasaran yang berbeda. Segmentasi pasar bisa diartikan sebagai proses pengidentifikasian dan menganalisis para pembeli dipasar produk, menganalisa perbedaan antara pembeli di pasar.

Variabel segmentasi pasar menurut Tjiptono dan Chandra $(2012,152)$ meliputi komponen berikut:

1. Demografis: usia, pendapatan, status pernikahan, tipe dan ukuran keluarga, gender, kelas sosial, dan lain-lain.

2. Psikografis: gaya hidup, nilai, dan karakteristik kepribadian.

3. Perilaku: situasi pemakaian, tingkat pemakaian, produk komplementer dan produk substitusi yang digunakan, loyalitas merek, dan lainlain.

4. Pengambilan keputusan: pilihan individu atau kelompok, pembelian keterlibatan tinggi atau rendah, sikap dan pengetahuan tentang kelas produk, sensitivitas harga, dan lainlain.

5. Pola media: tingkat pemakaian, tipe media yang digunakan, frekuensi pemakaian, dan lain-lain.

\section{Targeting}

Kotler dan Armstrong (2010, 225) "Target market consist of a set of buyers who share common needs or characteristics that the company decides to serve". Sesudah perusahaan mampu mengidentifikasi peluang pasar dari berbagai segmen pasar produknya, perusahaan harus menentukan cara bagaimana dan segmen mana yang akan dilayani kebutuhannya. Menurut Kotler dan Keller $(2009,250)$ setelah mengevaluasi berbagai segmen, perusahaan dapat mempertimbangkan lima pola pemilihan pasar sasaran, diantaranya:

1. Konsentrasi segmen tunggal; melalui pemasaran terkonsentrasi, perusahaan mendapatkan pengetahuan yang kuat tentang kebutuhan segmen dan kehadirannya di pasar akan kuat.

2. Spesialisasi selektif; perusahaan memilih sejumlah segmen, masing-masing secara objektif menarik dan tepat.

3. Spesialisasi produk; perusahaan membuat produk tertentu yang kemudian dijual ke beberapa segmen pasar.

4. Spesialisasi pasar; perusahaan berkonsentrasi untuk melayani berbagai kebutuhan dari satu kelompok pelanggan tertentu.

5. Cakupan pasar penuh; perusahaan berusaha melayani semua kelompok pelanggan dengan semua produk yang mungkin mereka perlukan.

Dalam bukunya Marketing, Ali Hasan $(2008,197)$ menyatakan bahwa terdapat beberapa kriteria penentuan target pasar, diantaranya:

1. Memastikan bahwa pasar yang dipilih itu harus cukup besar dan akan cukup menguntungkan bagi perusahaan dimasa mendatang. Untuk itu marketer harus menelaah kompetisi yang ada di target itu, dan potensinya untuk tumbuh, sebab ini tentu saja akan mempengaruhi ukuran dan pertumbuhan target segmen perusahaan.

2. Target pasar harus didasarkan pada keunggulan kompetitif perusahaan.

3. Target pasar yang dibidik harus mempertimbangkan situasi persaingan yang secara langsung atau tidak langsung mempengaruhi daya tarik target segmen.

\section{Positioning}

Menurut Gunawan Adisaputro (2014, 131) positioning adalah :

Suatu tindakan untuk mendesain tawaran dan citra perusahaan yang mampu menempati tempat yang distingif di benak pasar sasarannya 
sehingga tujuan positioning adalah menempatkan brand di benak konsumen untuk memaksimumkan manfaat potensial perusahaan.

Sedangkan pemosisian (positioning) menurut Cannon, et al (2008) "merupakan cara berpikir pelanggan mengenai merek yang diusulkan atau yang ada saat ini dalam suatu pasar". Umumnya strategi positioning yang bisa dipilih setiap perusahaan menurut Peter dan Olson (2014) sedikitnya ada 5 (lima) pendekatan untuk strategi pemosisian antara lain:

1. Pemosisian menurut atribut; mengasosiasikan suatu produk dengan atribut, ciri produk, atau ciri pelanggan.

2. Pemosisian menurut penggunaan atau aplikasi.

3. Pemosisian menurut pengguna produk.

4. Pemosisian menurut kelas produk

5. Pemosisian menurut pesaing.

\section{METODOLOGI PENELITIAN}

Data

Berdasarkan bentuknya, jenis data yang digunakan dalam penelitian ini yaitu data kualitatif yang dikuantitatifkan yaitu jawaban dari responden terhadap kuesioner yang dibagikan dan diterjemahkan dalam bentuk 6.

Tabel 1. Penentuan Jumlah Sampel

\begin{tabular}{lcc}
\hline \multicolumn{1}{c}{ Fakultas } & Anggota Populasi & Jumlah Sampel \\
\hline Pascasarjana & 645 & 18 \\
\hline F. Hukum & 1.208 & 33 \\
\hline F. Ekonomi & 2.880 & 79 \\
\hline F. KIP & 2.380 & 65 \\
\hline F. ISB & 2.162 & 59 \\
\hline F. Teknik & 1.305 & 36 \\
\hline F. MIPA & 3.200 & 88 \\
\hline Diploma & 358 & 10 \\
\hline Jumlah & $\mathbf{1 4 . 1 3 8}$ & $\mathbf{3 8 9}$ \\
\hline
\end{tabular}

\section{Variabel}

Untuk memudahkan dalam proses penelitian, terutama kaitannya dengan penjelasan karakteristik mahasiswa koding. Berdasarkan sumbernya, data yang digunakan tersebut berasal dari responden yaitu mahasiswa Universitas Pakuan, oleh karena itu termasuk dalam sumber primer.

\section{Populasi dan Sampel}

Populasi dalam penelitian ini adalah mahasiswa Universitas Pakuan yang berjumlah 14.138 orang. Metode pemilihan sampel yang digunakan adalah metode probabilitas cluster sampling. Penentuan jumlah sampel, digunakan metode Slovin dengan rumus sebagai berikut.

$$
n=\mathrm{N} /\left(1+\mathrm{N} \cdot \mathrm{e}^{2}\right)
$$

Berikut proses penarikan sampel:

1. Menentukan populasi target, yaitu mahasiswa Universitas Pakuan yang menggunakan jasa layanan transportasi online.

2. Mengelompokkan mahasiswa berdasarkan program.

3. Membuat kerangka sampel.

4. Menentukan jumlah sampel untuk masingmasing program menggunakan pendekatan proporsional.

5. Melakukan pengambilan sampel dari masing-masing program dengan metode simple random sampling. 
1. Variabel segmenting, dengan indikator geografis, demografis, psikografis, perilaku, pengambilan keputusan, dan pola media.

2. Variabel positioning, dengan indikator atribut produk, penggunaan produk, pengguna produk, kelas produk, pesaing.

3. Variabel targeting.

\section{Teknik Analisis}

Metode analisis data yang digunakan dalam penelitian ini sebagai berikut.

1. Uji Validitas dan Reliabilitas

Teknik untuk mengukur validitas kuesioner yaitu dengan menghitung korelasi antar skor masing-masing pernyataan dengan skor total, memakai rumus korelasi product moment.

Rumus Korelasi Product Moment:

$$
r=\frac{n \cdot \sum X Y-\sum X \cdot \sum Y}{\sqrt{n \cdot \sum X^{2}-\left(\sum X\right)^{2}} \cdot \sqrt{N \cdot \sum Y^{2}-\left(\sum Y\right)^{2}}}
$$

Item instrumen dianggap valid jika koefisien korelasi $(r)>0,3$.

Uji reliabilitas berguna untuk menetapkan apakah instrumen dapat digunakan lebih dari satu kali, paling tidak oleh responden yang sama akan menghasilkan data yang konsisten. Rumus yang digunakan untuk mengukur reliabilitas yaitu Spearman Brown.

Nilai koefisien reliabilitas yang baik adalah:

$r_{11}>0,7$ (cukup baik),

$r_{11}>0,8$ (baik).

Rumus Spearman Brown:

$r_{11}=\frac{2 . r_{b}}{1+r_{b}}$

$r_{11}=$ nilai koefisien korelasi Spearman Brown.

$\mathrm{rb}=$ koefisien korelasi antara total skor butir pertanyaan kelompok ganjil dan genap yang valid.

\section{Statistik Deskriptif}

Statistik deskriptif atau statistik deduktif, yaitu metode statistik yang digunakan untuk mengumpulkan, meringkas, menyajikan, dan mendeskripsikan data sehingga dapat memberikan informasi yang berguna. Data disajikan dalam bentuk ukuran pemusatan data (mean, median, dan modus), ukuran penyebaran data (standar deviasi dan varian), tabel, serta grafik (histogram, pie, polygon, dan bar). Ukuran-ukuran statistik deskriptif yang akan digunakan dalam penelitian ini antara lain: mean, tabel dan grafik.

\section{HASIL DAN PEMBAHASAN \\ Hasil penelitian \\ Profil Responden}

Berdasarkan metodologi penelitian yang telah dijelaskan sebelumnya, maka berikut ini hasil dari pengumpulan data yang telah dilakukan oleh peneliti.

Dalam penelitian ini profil responden terbagi menjadi 3 (tiga) kriteria yaitu berdasarkan fakultas, jenis layanan grab yang digunakan, dan hobi. Untuk mendapatkan data yang diperlukan melibatkan pengguna Grab sebanyak 393 sampel. Berikut hasil data responden yang merupakan mahasiswa Universitas Pakuan yang menggunakan transportasi Grab.

1. Fakultas

Berikut ini profil responden berdasarkan fakultas. 


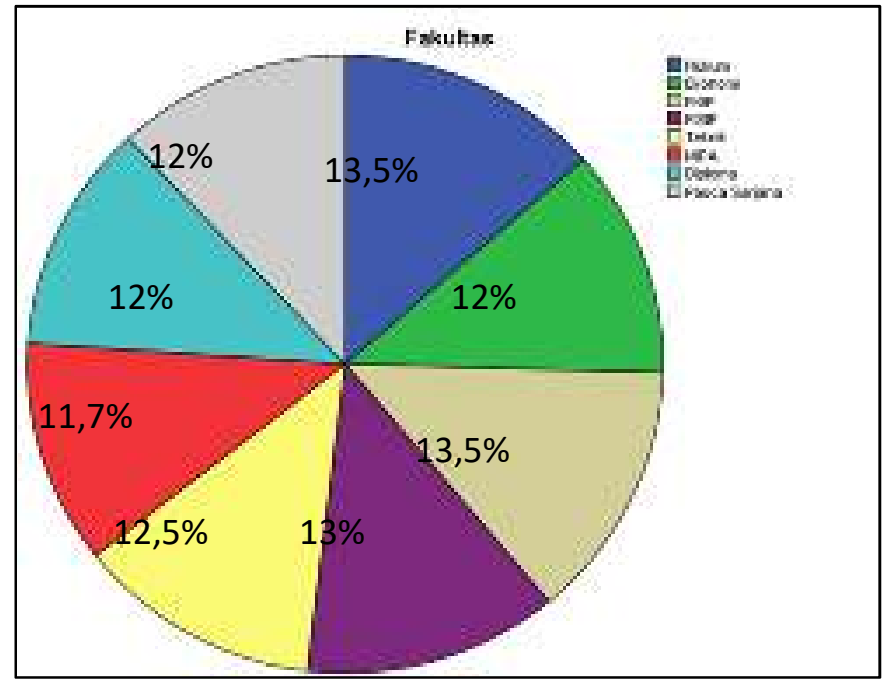

Gambar 1. Profil Responden Berdasarkan Fakultas Sumber: Data Kuesioner, diolah 2018

Berdasarkan gambar tersebut dapat dilihat bahwa dari 393 responden, 53 responden berasal dari Fakultas Hukum dengan persentase 13,5\%, 47 responden berasal dari Fakultas Ekonomi dengan persentase $12 \%$, 53 responden berasal dari FKIP dengan persentase 13,5\%, 51 responden berasal dari FISIB dengan persentase $13 \%$, 49 responden berasal Fakultas Teknik dengan persentase $12,5 \%$, 46 responden berasal dari FMIPA dengan persentase $11,7 \%, 47$ responden berasal dari Diploma dengan persentase $12 \%$, dan 47 responden berasal dari Pascasarjana dengan persentase $12 \%$.
2. Jenis layanan Grab yang digunakan Berikut ini profil responden berdasarkan jenis layanan Grab yang sering digunakan.

Tabel 2. Pengguna Grab Berdasarkan Jenis Layanan Grab yang Digunakan

\begin{tabular}{clcc}
\hline No. & Kategori & $\begin{array}{c}\text { Jumlah } \\
\text { Konsumen }\end{array}$ & Persentase \\
\hline 1 & Grab Bike & 267 & $67,9 \%$ \\
\hline 2 & Grab Car & 91 & $23,2 \%$ \\
\hline 3 & Grab Food & 31 & $7,9 \%$ \\
\hline 4 & Grab Taxi & 2 & $0,5 \%$ \\
\hline 5 & Grab Express & 2 & $0,5 \%$ \\
\hline & Jumlah & 393 & $100 \%$
\end{tabular}

Sumber: Data Kuesioner, diolah 2018 


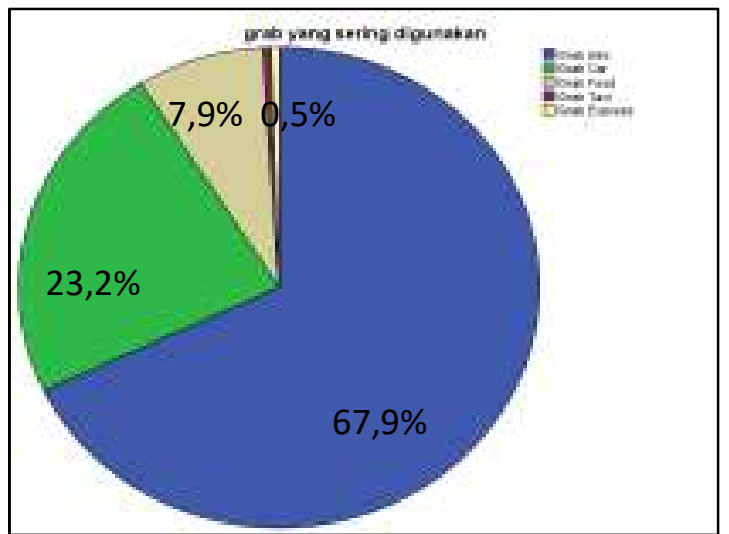

Gambar 2. Profil Responden Berdasarkan Jenis Layanan Grab yang Digunakan

Berdasarkan tabel di atas terlihat bahwa jenis layanan Grab yang digunakan sebanyak 267 responden menggunakan Grab Bike dengan persentase 67,9\%, 91 responden menggunakan Grab Car dengan persentase 23,2\%, 31 responden menggunakan Grab Food dengan persentase 7,9\%, 2 responden menggunakan Grab Taxi dengan persentase 0,5\%, dan 2 responden menggunakan Grab Express dengan persentase $0,5 \%$. Berdasarkan hasil diatas dapat disimpulkan bahwa jenis layanan yang sering digunakan oleh responden adalah Grab Bike.
3. Hobi

Berikut profil responden berdasarkan hobi:

Tabel 3. Pengguna Grab Berdasarkan Hobi

\begin{tabular}{cccc} 
No. & Kategori & $\begin{array}{c}\text { Jumlah } \\
\text { Konsumen }\end{array}$ & Persentase \\
\hline 1 & Travelling & 120 & $30,5 \%$ \\
\hline 2 & Membaca & 78 & $19,8 \%$ \\
\hline 3 & Olahraga & 53 & $13,5 \%$ \\
\hline 4 & $\begin{array}{c}\text { Kegiatan } \\
\text { Sosial }\end{array}$ & 40 & $10,2 \%$ \\
\hline 5 & Belanja & 60 & $15,3 \%$ \\
\hline 6 & Lainnya & 42 & $10,7 \%$ \\
\hline & Jumlah & 393 & $100 \%$ \\
\hline
\end{tabular}

Sumber: Data Kuesioner, diolah 2018

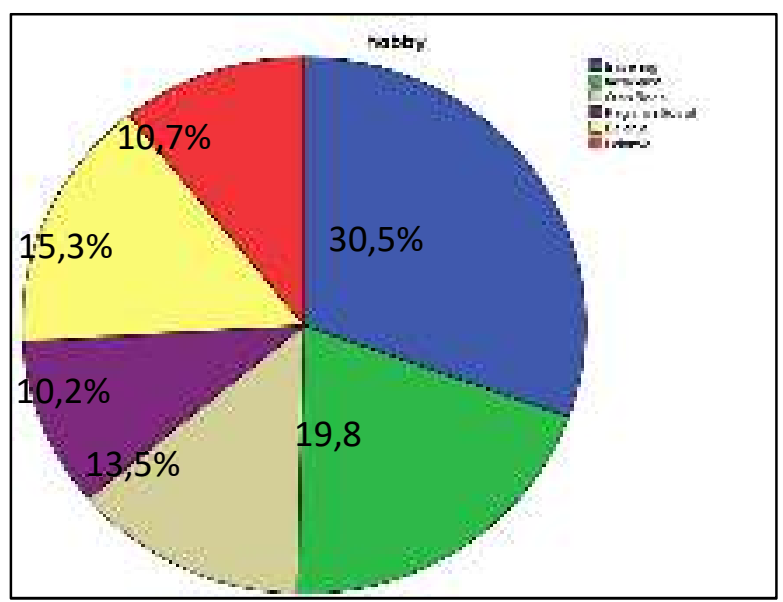

Gambar 3. Profil Responden Berdasarkan Hobi

Berdasarkan tabel diatas terlihat bahwa 120 responden memiliki hobbi travelling dengan persentase $30,5 \%, 78$ responden memiliki hobi membaca dengan 
persentase 19,8\%, 53 responden memiliki hobi olahraga dengan persentase $13,5 \%, 40$ responden memiliki hobi kegiatan sosial dengan persentase 10,2\%, 60 responden memiliki hobi belanja dengan persentase $15,3 \%$, dan 42 responden memiliki hobi diluar yang disebutkan dengan persentase $10,7 \%$. Berdasarkan hasil diatas dapat disimpulkan bahwa pengguna Grab paling banyak adalah responden yang memiliki hobi traveling dibandingkan dengan hobi lainnya.

\section{Hasil Uji Validitas dan Uji Reliabilitas}

Pengujian validitas dan reliabilitas dilakukan untuk kuesioner berkaitan dengan variabel positioning. Hal ini dilakukan untuk mengetahui apakah butir-butir kuesioner yang digunakan valid (tepat) dan reliable (handal) untuk mengukur variabel positioning. Uji validitas dengan menggunakan metode koefisien korelasi product moment, sedangkan pengujian reliabilitas dengan menggunakan metode split-half. Kuesioner dikatakan valid jika koefisien korelasi lebih dari 0,3. Hasil pengujian validitas dan reliabilitas ditunjukkan pada tabel berikut ini.

Tabel 4. Hasil Uji Validitas Kuesioner Positioning

\begin{tabular}{cccc}
\hline Butir & $\mathbf{R}$ & Batas & Valid/Tidak \\
\hline B1 & 0,6380 & 0,3 & Valid \\
\hline B2 & 0,4438 & 0,3 & Valid \\
\hline B3 & 0,5345 & 0,3 & Valid \\
\hline B4 & 0,7242 & 0,3 & Valid \\
\hline B5 & 0,4888 & 0,3 & Valid \\
\hline B6 & 0,5795 & 0,3 & Valid \\
\hline B7 & 0,4006 & 0,3 & Valid \\
\hline B8 & 0,5637 & 0,3 & Valid \\
\hline B9 & 0,3174 & 0,3 & Valid \\
\hline B10 & 0,3820 & 0,3 & Valid \\
\hline
\end{tabular}

\begin{tabular}{cccc}
\hline Butir & $\mathbf{R}$ & Batas & Valid/Tidak \\
\hline B11 & 0,3501 & 0,3 & Valid \\
\hline B12 & 0,3194 & 0,3 & Valid \\
\hline B13 & 0,5481 & 0,3 & Valid \\
\hline B14 & 0,5199 & 0,3 & Valid \\
\hline B15 & 0,6595 & 0,3 & Valid \\
\hline B16 & 0,6925 & 0,3 & Valid \\
\hline B17 & 0,7553 & 0,3 & Valid \\
\hline B18 & 0,5663 & 0,3 & Valid \\
\hline B19 & 0,5731 & 0,3 & Valid \\
\hline B20 & 0,7011 & 0,3 & Valid \\
\hline & \multicolumn{3}{c}{ Sumber: diolah, 2018. }
\end{tabular}

Hasil pengujian menunjukkan bahwa dari 20 butir kuesioner yang digunakan, semuanya dinyatakan valid karena memiliki koefisien korelasi lebih dari 0,3.

Setelah dilakukan uji validitas, selanjutnya butir-butir yang valid diuji reliabilitasnya dengan menggunakan metode split-half. Hasil pengolahan menunjukkan koefisien korelasi total sebesar 0,858 , artinya kuesioner tersebut memiliki reliabilitas yang kuat sehingga dapat digunakan sebagai instrumen dalam penelitian ini untuk mengukur variabel positioning.

\section{Pembahasan}

\section{Segmenting Transportasi Online Grab di Kota} Bogor

Untuk mendapatkan gambaran secara mendalam mengenai segmentasi pasar dari Grab, dilakukan pengelompokkan pasar ke dalam beberapa dimensi, diantaranya geografis, demografis, psikografis, perilaku, pengambilan keputusan, dan pola media. Berdasarkan kuesioner yang disebar kepada 393 responden pengguna Grab yang merupakan mahasiswa Universitas Pakuan di Kota Bogor, diperoleh hasil sebagai berikut. 
Tabel 5. Segmentasi Transportasi Online di Kota Bogor

\begin{tabular}{|c|c|c|c|}
\hline Dimensi & Indikator & $\mathbf{F}$ & $\%$ \\
\hline \multirow[t]{3}{*}{ Geografis } & Domisili & & \\
\hline & - Bogor Barat & 83 & 21,1 \\
\hline & - Bogor Timur & 77 & 19,6 \\
\hline \multirow[t]{10}{*}{ Demografis } & Usia & & \\
\hline & $-18-24$ tahun & 332 & 84,5 \\
\hline & Jenis Kelamin & & \\
\hline & - Wanita & 258 & 65,6 \\
\hline & Penghasilan & & \\
\hline & $-0-2,5$ juta & 331 & 84,2 \\
\hline & Status Pernikahan & & \\
\hline & - Belum Menikah & 352 & 89,6 \\
\hline & Kelas Sosial & & \\
\hline & - Menengah & 332 & 84,5 \\
\hline \multirow[t]{5}{*}{ Psikografis } & Gaya Hidup & & \\
\hline & - Rumahan & 147 & 37,4 \\
\hline & - Orang untuk orang lain & 97 & 24,7 \\
\hline & Kepribadian & & \\
\hline & - Extrovert & 269 & 68,4 \\
\hline \multirow[t]{13}{*}{ Perilaku } & Situasi Pemakaian/waktu penggunaan & & \\
\hline & - Bepergian & 225 & 57,3 \\
\hline & Produk Komplementer & & \\
\hline & - Iya & 325 & 82,7 \\
\hline & Produk Substitusi & & \\
\hline & - Iya & 272 & 69,2 \\
\hline & Loyalitas & & \\
\hline & - Cukup loyal & 271 & 69,0 \\
\hline & Manfaat yang dicari & & \\
\hline & - Kemudahan & 163 & 41,5 \\
\hline & - Kecepatan & 78 & 19,8 \\
\hline & Metode Pembayaran & & \\
\hline & - Tunai & 348 & 88,5 \\
\hline \multirow[t]{9}{*}{$\begin{array}{l}\text { Pengambilan } \\
\text { Keputusan }\end{array}$} & $\begin{array}{l}\text { Faktor Yang Mempengaruhi Keputusan / } \\
\text { Pilihan }\end{array}$ & & \\
\hline & - Pribadi Sendiri & 236 & 60,1 \\
\hline & Frekuensi Penggunaan & & \\
\hline & - Kadang-kadang & 222 & 56,5 \\
\hline & Pengetahuan akan Produk & & \\
\hline & - Tahu & 238 & 60,6 \\
\hline & Sensitifitas harga/Alasan memilih produk & & \\
\hline & - Harga lebih murah dibanding pesaing & 180 & 45,8 \\
\hline & - Banyak potongan harga & 119 & 30,3 \\
\hline \multirow[t]{2}{*}{ Pola Media } & Tipe Media yang digunakan & & \\
\hline & - Aplikasi Grab & 221 & 56,2 \\
\hline
\end{tabular}




\section{Targeting Transportasi Online Grab di Kota Bogor}

Berdasarkan hasil pengelompokkan segmen diatas dari variabel geografis terlihat bahwa mahasiswa pengguna Grab berasal dari wilayah Bogor Barat sebanyak $21,1 \%$ dan Bogor Timur sebanyak 19,6\%. Variabel demografis menunjukkan bahwa mahasiswa pengguna Grab berasal dari jenis kelamin wanita sebanyak $65,6 \%$, dari sisi kelas sosial mahasiswa pengguna Grab berasal dari kelas menengah dengan persentase $84,5 \%$. Variabel Psikografis menunjukkan bahwa mahasiswa pengguna Grab merupakan pribadi yang extrovert sebanyak $68,4 \%$, pribadi extrovert yaitu pribadi yang senang bergaul, ceria, berjiwa sosial dan bersifat humoris, dimana pribadi extrovert adalah pribadi yang memiliki banyak teman.

Variabel perilaku menunjukkan bahwa mahasiswa pengguna Grab menggunakan layanan Grab untuk bepergian dengan persentase 57,3\%, dari sisi produk komplementer yang artinya Grab menyediakan fasilitas berupa perlengkapan bagi penumpang seperti helm, masker, penutup kepala dan jas hujan sebanyak $82,7 \%$ responden menyatakan fasilitas tersebut tersedia, dari sisi produk substitusi yaitu dimana mahasiswa pengguna Grab selain menggunakan Grab juga menggunakan jasa transportasi lain seperti Gojek dan/atau ojek pangkalan sebanyak $69,2 \%$ menyatakan iya, yang berarti mahasiswa pengguna Grab juga menggunakan layanan Gojek dan/atau ojek pangkalan, hal ini didukung dengan jawaban responden dari sisi loyalitas yaitu sebanyak $69 \%$ menyatakan cukup loyal. Dari sisi manfaat yang dicari oleh para pengguna dalam menggunakan Grab adalah karena kemudahan sebanyak $41,5 \%$ dan kecepatan sebanyak $19,8 \%$.

Variabel pengambilan keputusan menunjukkan bahwa mahasiswa pengguna Grab menggunakan layanan Grab karna keputusan pribadi dengan persentase $60,1 \%$. Dari sisi frekuensi penggunaan sebanyak $56,5 \%$ responden menyatakan kadang-kadang menggunakan Grab, yang berarti ada transportasi lain yang digunakan oleh para responden. Sedangkan dari sisi pengetahuan akan produk atau layanan Grab sebanyak 60,6\% responden mengetahui tentang Grab. Sisi sensitifitas harga sebanyak $45,8 \%$ menyatakan alasan menggunakan Grab karna harga yang lebih murah dibanding pesaing dan 30,3\% dikarenakan banyaknya potongan harga yang diberikan oleh Grab. Sedangkan dari variabel pola media, mahasiswa pengguna Grab mendapatkan informasi tentang layanan Grab termasuk promo-promo yang ditawarkan melalui aplikasi Grab yang terpasang pada smartphone para pengguna sebanyak $56,2 \%$.

Evaluasi segmen diatas memberikan gambaran bagi Grab untuk memilih target market dengan pola Spesialisasi Selektif. Pada spesialisasi selektif, perusahaan memilih sejumlah segmen pasar yang atraktif dan sesuai dengan tujuan dan sumber daya yang dimiliki (Fandy Tjiptono \& Gregorius Chandra,2012,156). Dalam hal ini yang menjadi pilihan Grab sebagai target marketnya adalah segmen transportasi dan jasa pengiriman barang. Target market ini sejalan dengan tanggapan responden yang menggunakan Grab karna kemudahan dan kecepatan, selain itu hal ini didukung dengan layanan yang ditawarkan oleh Grab. Untuk transportasi Grab menawarkan layanan yang berupa: Ojek (Grab Bike), Mobil (Grab Car), Taksi (Grab Taxi), Grab Hitch (nebeng), dan Grab Sewa. Untuk jasa layanan pengiriman barang terdapat Kurir (Grab Delivery), Grab Parcel (layanan kurir dengan waktu pengiriman yang dapat disesuaikan dengan kebutuhan pengguna dan harga yang lebih ekonomis), sedangkan untuk jasa pembelian makanan terdapat layanan Grab Food.

Layanan yang ditawarkan Grab sejalan dengan perilaku pemakaian penggunanya yang menggunakan Grab untuk bepergian, sehingga Grab banyak menawarkan alternatif pilihan transportasi mulai dari motor sampai mobil 
pribadi. Jika ingin bepergian dengan mobil pribadi dan lebih hemat bisa menggunakan Grabhitch, dimana penumpang dipertemukan dengan pengemudi yang searah dengan rutenya dan biaya sharing dengan penumpang lain yang juga menggunakan Grabhitch. Bagi pengguna yang sedang dalam liburan atau mau bepergian ke beberapa lokasi bisa menggunakan Grabsewa dimana pengguna bisa menggunakan aplikasi Grab untuk mendapatkan mobil sewaan.

Variasi Layanan yang ditawarkan Grab berfokus kepada memberikan kemudahan dalam bertransportasi, dan Grab tidak menawarkan layanan diluar transportasi sebanyak seperti yang ditawarkan pesaingnya. Hal ini menunjukkan bahwa Grab memilih segmen pasar transportasi dan pengiriman sebagai target marketnya.

\section{Positioning Transportasi Online Grab di Kota Bogor}

Pembahasan positioning transportasi online Grab di Kota Bogor dilakukan dengan berdasarkan hasil jawaban responden terhadap kuesioner yang meliputi variabel atribut produk, penggunaan produk, pengguna produk, kelas produk dan pesaing. Berikut adalah hasil dari simpulan tanggapan responden untuk variabel positioning:

Tabel 6. Hasil Tanggapan Responden Untuk Variabel Positioning

\begin{tabular}{|c|c|c|c|}
\hline No & Variabel Positioning & $\begin{array}{l}\text { Tanggapan } \\
\text { Responden } \\
\text { (\%) }\end{array}$ & $\begin{array}{l}\text { Rata- } \\
\text { Rata }\end{array}$ \\
\hline \multirow[t]{4}{*}{1.} & Atribut Produk & & $59,20 \%$ \\
\hline & $\begin{array}{l}\text { 1.Grab merupakan transportasi online yang terkenal } \\
\text { di Indonesia dan Internasional }\end{array}$ & $55,70 \%$ & \\
\hline & $\begin{array}{l}\text { 2.Grab memiliki ciri khas dari seragamnya dan } \\
\text { helmnya }\end{array}$ & $63,60 \%$ & \\
\hline & 3.Grab mudah diperoleh di daerah manapun. & $58,30 \%$ & \\
\hline \multirow[t]{4}{*}{2.} & Variabel Penggunaan Produk & & $75,77 \%$ \\
\hline & $\begin{array}{l}\text { 1.Grab membantu konsumen untuk sampai ke lokasi } \\
\text { tujuan dengan lebih cepat dan nyaman }\end{array}$ & $77,40 \%$ & \\
\hline & $\begin{array}{l}\text { 2.Grab memberikan solusi kemudahan dalam jasa } \\
\text { layanan antar }\end{array}$ & $75,10 \%$ & \\
\hline & 3.Grab memberikan rasa aman kepada penggunanya & $74,80 \%$ & \\
\hline \multirow[t]{4}{*}{3.} & Variabel Pengguna Produk & & $58,27 \%$ \\
\hline & $\begin{array}{l}\text { 1.Pengguna Grab pada umumnya ingin } \\
\text { mendapatkan layanan transportasi yang murah, } \\
\text { aman dan nyaman }\end{array}$ & $57,50 \%$ & \\
\hline & $\begin{array}{l}\text { 2.Pengguna Grab pada umumnya adalah para } \\
\text { pekerja dan pelajar }\end{array}$ & $54,50 \%$ & \\
\hline & 3.Pengguna Grab paham teknologi (tidak gaptek) & $62,80 \%$ & \\
\hline \multirow[t]{3}{*}{4.} & Variabel Kelas Produk & & $58,50 \%$ \\
\hline & $\begin{array}{l}\text { 1.Grab adalah jasa transportasi pengganti angkot, } \\
\text { bus dan ojek pangkalan }\end{array}$ & $54,20 \%$ & \\
\hline & $\begin{array}{l}\text { 2. Grab tidak sekedar jasa transportasi namun juga } \\
\text { jasa pengiriman barang }\end{array}$ & $62,80 \%$ & \\
\hline 5. & Variabel Pesaing & & $59,52 \%$ \\
\hline
\end{tabular}




\begin{tabular}{|c|c|c|c|}
\hline No & Variabel Positioning & $\begin{array}{c}\text { Tanggapan } \\
\text { Responden } \\
(\%)\end{array}$ & $\begin{array}{l}\text { Rata- } \\
\text { Rata }\end{array}$ \\
\hline & $\begin{array}{l}\text { 1.Grab memiliki driver lebih banyak dibandingkan } \\
\text { dengan pesaingnya }\end{array}$ & $54,70 \%$ & \\
\hline & $\begin{array}{l}\text { 2.Grab lebih digemari oleh mahasiswa dibandingkan } \\
\text { pesaingnya }\end{array}$ & $51,40 \%$ & \\
\hline & $\begin{array}{l}\text { 3. Driver Grab lebih ramah dan sopan dibanding } \\
\text { driver pesaing }\end{array}$ & $57,80 \%$ & \\
\hline & $\begin{array}{l}\text { 4. Grab lebih banyak memberikan potongan harga } \\
\text { dan bonus dibandingkan pesaingnya }\end{array}$ & $60,60 \%$ & \\
\hline & $\begin{array}{l}\text { 5.Grab lebih cepat dan mudah diperoleh dibanding } \\
\text { pesaing }\end{array}$ & $67,70 \%$ & \\
\hline & $\begin{array}{l}\text { 6. Grab menawarkan variasi layanan lebih banyak } \\
\text { dibandingkan pesaingnya. }\end{array}$ & $64,90 \%$ & \\
\hline
\end{tabular}

\section{Sumber: diolah 2018}

Berdasarkan tabel hasil tanggapan responden untuk variabel positioning terlihat bahwa variabel penggunaan produk memiliki rata-rata tanggapan responden per variabel yang paling besar nilainya yaitu $75,77 \%$. Variabel penggunaan produk yang paling besar terlihar dari indikator Grab membantu konsumen untuk sampai ke lokasi tujuan dengan lebih cepat dan nyaman sebesar $77,4 \%$, dan indikator Grab memberikan solusi kemudahan dalam jasa layanan antar sebesar $75,1 \%$. Sedangkan variabel yang memiliki ratarata tanggapan responden terendah adalah variabel pengguna produk dengan indikator terendah yaitu pengguna Grab pada umumnya adalah para pekerja dan pelajar sebesar $54,5 \%$.

Dari hasil diatas maka untuk melakukan positioning, Grab dapat menggunakan strategi application positioning (pemosisian menurut penggunaan atau aplikasi). Pada appllication positioning, produk diposisikan sebagai alternatif terbaik untuk situasi pemakaian atau aplikasi tertentu (Tjiptono \& Chandra, 2012,161). Hal ini dapat diartikan bahwa Grab diposisikan sebagai alat trasnportasi yang mudah, cepat, aman, dan nyaman.

\section{PENUTUP}

Berdasarkan hasil dan pembahasan, dapat diambil kesimpulan sebagai berikut:

1. Segmenting pengguna Grab dari mahasiswa Universitas Pakuan dikelompokkan ke dalam enam segmen yang terdiri dari segmen geografis, segmen demografis, segmen psikografis, segmen perilaku, segmen pengambilan keputusan dan segmen pola media. Segmen geografis menunjukkan bahwa mahasiswa Universitas Pakuan pengguna Grab paling besar berdomisili di daerah Bogor Barat sebanyak 83 orang atau $21,1 \%$. Segmen demografis berdasarkan jenis kelamin paling banyak adalah wanita sebanyak 258 orang atau $65,6 \%$, dan dari sisi kelas sosial merupakan kelas menengah sebanyak 332 orang atau $84,5 \%$. Segmen psikografis menunjukkan bahwa mahasiswa pengguna Grab adalah yang memiliki gaya hidup rumahan sebesar 147 orang atau $37,4 \%$, dan dilihat dari sisi kepribadian sebanyak 269 orang atau $68,4 \%$ memiliki kepribadian extrovert. Segmen perilaku menunjukkan bahwa dari situasi pemakaian sebanyak 225 responden atau $57,3 \%$ mahasiswa pengguna Grab menggunakan Grab untuk bepergian, dari sisi loyalitas sebanyak 271 orang atau 69\% 
responden cukup loyal, dari sisi manfaat yang dicari sebanyak 163 orang atau $41,5 \%$ menjawab mencari kemudahan sedangkan 78 orang atau $19,8 \%$ menjawab mencari kecepatan. Segmen pengambilan keputusan menunjukkan bahwa mahasiswa pengguna Grab dalam menentukan pilihan menggunakan Grab didasarkan atas pribadi sendiri sebanyak 236 orang atau $60,1 \%$, dari sisi frekuensi Grab digunakan untuk waktu tertentu saja (kadang-kadang) sebanyak 222 orang atau 56,5\%, dari sisi pengetahuan akan produk sebanyak 238 orang atau $60,6 \%$ responden mengetahui tentang Grab, dari sisi sensitifitas harga sebanyak 180 orang atau 45,8\% dikarenakan harga Grab lebih murah dibanding dengan pesaing dan 119 responden atau 30,3\% memilih banyak potongan harga sebagai alasan memilih Grab. Segmen pola media menunjukkan bahwa mahasiswa pengguna Grab mengetahui informasi tentang Grab termasuk promo-promo yang ditawarkan melalui aplikasi Grab sebanyak 221 orang atau $56,2 \%$.

2. Target market yang tepat untuk Grab berdasarkan hasil evaluasi segmen yang telah dilakukan adalah Spesialisasi Selektif. Untuk memenuhi kebutuhan pasar akan transportasi yang murah, aman, nyaman, cepat dan mudah Grab hadir dengan layanan Grab bike untuk transportasi dengan motor, Grab car untuk transportasi mobil pribadi, Grab Taxi untuk transportasi mobil yang bekerjasama dengan perusahaan taxi tertentu, Grab hitch untuk transportasi mobil dengan konsep nebeng dimana penumpang yang satu arah tujuan dipertemukan dengan satu driver sehingga biaya perjalanan bisa dishare ke beberapa orang, dan Grab sewa yang menyediakan jasa penyewaan mobil jika bepergian lebih dari satu tempat. Sedangkan untuk segmen pengiriman barang, Grab memanfaatkan layanan transportasi Grab bike yang dimilikinya dengan membuat layanan antar barang yang diberi nama Grab delivery, Grab parcel, dan untuk layanan pemesanan makanan dibuat layanan Grab food. Segmen yang diambil oleh Grab lebih selektif jika dibandingkan dengan pesaingnya yaitu Gojek, dimana Gojek menawarkan banyak jasa diluar tranportasi seperti Go-Clean, Go-Massage, Go-Box, GoTix, dll.

3. Positioning ditentukan dengan tujuan untuk membentuk citra merek tertentu di benak konsumen. Dalam penelitian ini digunakan lima pendekatan yang digunakan untuk positioning, yaitu menurut atribut produk, penggunaan produk, pengguna produk, kelas produk, dan menurut pesaing. Berdasarkan hasil pengolahan kuesioner yang disebar, diperoleh rata-rata tanggapan responden terbesar pada variabel penggunaan produk sebesar 75,77\%, sedangkan variabel dengan rata-rata tanggapan responden terendah terdapat pada variabel pengguna produk. Indikator terbesar pada variabel penggunaan produk yaitu Grab membantu konsumen untuk sampai ke lokasi tujuan dengan lebih cepat dan nyaman dengan persentase $77,4 \%$ responden menyatakan setuju, dikuti dengan $75,1 \%$ menyatakan setuju pada indikator Grab memberikan solusi kemudahan dalam jasa layanan antar. Dari kedua indikator ini Grab dapat memposisikan merek nya dibenak konsumen dari sisi penggunaan, yaitu sebagai alat transportasi dan jasa layanan yang memberikan kemudahan, kenyamanan, aman, dan cepat.

\section{REFERENSI}

Adisaputro, G. (2014). Manajemen Pemasaran: Analisis Untuk Perancangan Strategi Pemasaran. Yogyakarta: Sekolah Tinggi IImu Manajemen YKPN.

Amstrong, Gary, \& Kotler, P. (2010). Principles of Marketing. 13th Edition. New Jersey: Pearson Education Inc. 
Cannon, Joseph P., et al. (2008). Pemasaran Dasar Pendekatan Manajerial Global. Edisi 16. Buku 1. Alih Bahasa: Afia R. Fitriani dan Ria Cahyani. Jakarta: Salemba Empat.

Chandra, G., \& Tjiptono F. (2012). Pemasaran Strategik. Yogyakarta: C.V Andi Offset.

Hasan, A. (2008). Marketing. Yogyakarta: Media Pressindo.

Ichsan, N. (2017). Ini hasil lengkap survei YLKI 41 persen pengguna pernah dikecewakan. 12 Mei 2017. Tersedia di http://wartakota.tribunnews.com/2017 105/12/.

Iskandar. (2017). Persaingan sengit gojek dan grab dan uber siapa pemenangnya. 8 November 2017. https://www.liputan6.com/tekno/read/ 3155394/.

Keller, K.L., \& Kotler, P. (2009). Manajemen Pemasaran Edisi 13 Jilid 1. Alih bahasa: Bob Sabran, MM. Jakarta: Erlangga.

Kristo, Yurio F. (2017). Awal mula transportasi online menjamur di Indonesia. 22 Agustus 2017. Tersedia di: https://inet.detik.com/cyberlife/d3609781/.

Mullins, John W., \& Jr. Walker, Orville C. (2013). Marketing Management: A Strategic Decision Making Approach. 8th Edition. New York: Mc Graw-Hill.
Oentoro, Deliyanti. (2012). Manajemen Pemasaran Modern. Yogyakarta: LaksBang Pressindo.

Peter, J. Paul., \& Olson, Jerry C. (2014). Perilaku Konsumen dan Strategi Pemasaran. Edisi 9. Buku 2. Alih Bahasa: Diah Tantri Dwiandani. Jakarta: Salemba Empat.

Sutojo, S. (2009). Manajemen Pemasaran Untuk Eksekutif Non-Pemasaran. Edisi Kedua. Jakarta: PT Damar Mulia Pustaka.

Sylvia, S. dan Kholid, M. (2016). Analisis Segmenting, Targeting, dan Positioning Dalam Rangka Meningkatkan Daya Saing Melalui Strategi Pemasaran Di Toko PIA Cap Mangkok Cabang Semeru. Jurnal administrasi dan bisnis, Vol. 39, No.2, Oktober 2016.

Techinesia. (2017). Sejarah transportasi online di Indonesia. 4 Juni 2017. Tersedia di: http://www. .transonlinewatch.com.

Wijaya, H., \& Sirine, H. (2016). "Strategi Segmenting, Targeting, Positioning Serta Strategi Harga Pada Perusahaan Kecap Blekok Di Cilacap", dalam Asian Journal of Innovation and Entrepreneurship (e-ISSN: 2477-0574; pISSN: 2477-3824), Vol. 01, No. 03, September 2016. 
